\title{
Perspective of Social Capital into Poverty Level of the Community, Case Study Bumiaji District, Batu City, Indonesia
}

\author{
Ismu Rini Dwi Ari \\ Department of Regional and Urban \\ Planning, Universitas Brawijaya, Jl. \\ MT. Haryono 167, Malang City, \\ East Java, Indonesia, 65145
}

\author{
Budi Soegiarto Waloejo \\ Department of Regional and Urban \\ Planning, Universitas Brawijaya, Jl. \\ MT. Haryono 167, Malang City, \\ East Java, Indonesia, 65145
}

\author{
Septiana Hariyani \\ Department of Regional and Urban \\ Planning, Universitas Brawijaya, Jl. \\ MT. Haryono 167, Malang City, East \\ Java, Indonesia, 65145
}

\begin{abstract}
Some empirical research says that social factors can be dealing with poverty. So aims of the research are to measure i) poverty level, and ii) social capital in order to have an appropriate understanding of the perspective of social capital into poverty level of the community. This research study is conducted in Bumiaji District consist of 9 villages with number of sample at about 275 households divided proportionately between poor and nonpoor households. Poverty values of the region are calculated with Multidimensional Poverty Index (MPI) covering three dimensions (health, education and living standard). The result indicates that the whole villages have a very low classification of the MPI. However, the dimension of education and living standard give significant contribution of deprivation toward the MPI. The measurement of social capital through affiliation data of the respondents' membership into the existing institutions covering three indexes - rate of participation, density, and centrality. The general result illustrates that each village has good social capital (high and medium level) indicated by value of participation rate and density, and a close network among the members of community within the village (high - low - high degree - betweenness closeness centrality's pattern). The high social relations of the community also indicates that there is no central actor who stands out in the activity because of between communities there is a close relationship between the community members. In conclusion, it could be seen that a community with good social capital might have ability to deal with poverty problems. Social capital is no longer only seen from how many institutions exist in society but rather emphasizes the glue that binds the community together for developing better access to information and resources.
\end{abstract}

Keywords; Multidimensional poverty index; social capital; social network analysis; the rate of participation; density; centrality

\section{INTRODUCTION}

Poverty is one of the most worldwide problems, especially in developing countries. Poverty has many effects on society because lack of basic service such as lack of education, health and children live. Households that have a better community connection, have ability to manage their problem by community-based management system [Ari, et.a 2011]. The household who have more frequent social interaction can assume that their influence each other and can adapt the preference of others [Ari, et.al 2011]. Good social relations between community can be a tool for the community to alleviate themselves from poverty. The social ties on communities will make the flow of information and resources between people easier so the opportunity to make them more prosperous will be even greater [Putnam,2000].

Social capital has an understanding as to the institutions, relationships, and norms that shape the quality and quantity of social interactions that occur in society [World Bank, 2001]. Social capital is no longer only seen from how many institutions exist in society but rather emphasizes the glue that binds the community together [Alfiah et.al, 2017]. Members in the community are more homogeneous by having a variety of similarities, namely the same expectations to create high solidarity [Santoso, 2009].

Social capital has an important role in the development of an area where social capital will increase the provision of public access to the availability of capital, education, health, and security [Vippriyanti, 2011]. In general, social capital influences household welfare, when a household has high social capital, the household will have higher per capita expenditure so that the opportunity to have more assets will be greater. Large social capital will be a medium for the community to conduct transactions in the scope of individuals, households, and groups in the form of information and resource transactions [Alfiah et.al, 2017].

The research study is conducted in Bumiaji District, Batu City consists of 9 villages, namely Pandanrejo, Bumiaji, Bulukerto, Gunungsari, Punten, Tulungrejo, Sumbergondo, Giripurno, and Sumberbrantas. First research aim is to measure poverty level of each village through the three dimensions of Multidimensional Poverty Index (MPI) that is introduced by Human Development Report [2015] and Oxford Poverty and Human Development Initiative [2010]. Then, the understanding of poverty level and the composition of poverty will be utilized to develop appropriate poverty reduction strategy [Team MPI Research, 2015]. The second aim is to measure social capital of the community in each village wherein Ari [2011] and Ari et.al [2013, 2017, 2018] has proposed three indexes measurement of social capital Density, Rate of Participation (RoP), and Centrality using Social Network Analysis (SNA) that the formula is developed by Wasserman and Faust [1994]. Finally, this research is 
trying to prove a basic assumption that a community with strong social capital might have developed their self as a nonpoverty community.

\section{METHOD}

\section{A. Data Collection and Sampling}

Primary data were collected through face-to-face questionnaire survey to the head of households in the 9 villages, whereby using Slovin formula the number of samples is 275 households among the total number of 47.602 households in the district. In order to have an appropriate representative data, the sample is divided into the poor and noon poor households proportionately. Particular primary data for the social capital measurement using SNA is in the type of affiliation data of the households membership into existing institutions in the village. Then, the secondary data were compiled from each village and district government office in the district.

TABLE I. NUMBER OF RESPONDENT SAMPLES OF EACH VILLAGE IN BUMIAJI DISTRICT

\begin{tabular}{|c|c|c|c|c|c|}
\hline No. & Villages & Samples & $\begin{array}{c}\text { \% samples } \\
\text { from total } \\
\text { households }\end{array}$ & $\begin{array}{c}\text { Samples } \\
\text { of poor } \\
\text { household }\end{array}$ & $\begin{array}{c}\text { Samples } \\
\text { of non- } \\
\text { poor } \\
\text { household }\end{array}$ \\
\hline 1 & Pandanrejo & 23 & $8 \%$ & 3 & 20 \\
\hline 2 & Bumiaji & 33 & $12 \%$ & 4 & 29 \\
\hline 3 & Bulukerto & 29 & $11 \%$ & 4 & 25 \\
\hline 4 & Gunungsari & 32 & $12 \%$ & 4 & 28 \\
\hline 5 & Punten & 26 & $9 \%$ & 2 & 24 \\
\hline 6 & Tulungrejo & 44 & $16 \%$ & 3 & 41 \\
\hline 7 & Sumbergondo & 18 & $7 \%$ & 1 & 42 \\
\hline 8 & Giripurno & 48 & $17 \%$ & 6 & 20 \\
\hline 9 & $\begin{array}{c}\text { Sumber } \\
\text { Brantas }\end{array}$ & 22 & $8 \%$ & 2 & 17 \\
\hline
\end{tabular}

\section{B. Multidimensional Poverty Index (MPI)}

The poverty level is based on the MPI (Multidimensional Poverty Index) looking at poverty from 3 dimensions there are education, health, and living standards. The educational dimension is measured based on the 2 indicator - years of schooling (12-year schooling) and attendance of school (between the age of $6-23$ years old )with the weight of each indicator is 0.167 . The health dimension discusses child malnutrition (children under 5 years old) and mortality of children under 5 years old (incident last 5 years), the weight of each indicator is 0.167 While the third dimension is the standard of living which consists of 6 indicators with each weight of indicators is 0.0556 :

1. Access to clean water (household that using nonpiping drinking water (river, well, spring) can be deprived as poor households)

2. Availability of sanitation networks (households with no sanitation and communal sanitation can be deprived as poor)

3. The availability of electricity networks (household that have no access to electricity can be deprived as poor)
4. Building floor (households that deprived as poor if using not feasible floor pavement (soil, sandland, animal feces))

5. Fuel for cooking (considered poor if still using firewood)

6. Ownership of assets

(At least one household has 1 asset from the information asset group and 1 asset from the mobility asset group or a household has 1 information group asset and livelihood assets)

Each respondent is rated 0 or 1 . When a respondent in a family member fulfills the indicator, it is given a value of 1 , otherwise, if the respondent does not meet the indicators above, it will be given a value of 0 . A household is identified as a poor household if the value of $C_{i} \geq 0.33$.

\section{Social Network Analysis (SNA)}

The three indexes - Rate of Participation (RoP), Density, and Centrality that are used in the research is referred to a method to analyze the social structure of the community using networks and graph theory developed by Wasserman \& Faust [1994]. The specific type of data for the SNA is called affiliation data, wherein incidence matrix $(n \times m)$ is formed by memberships of the respondents into community groups of each village. Using Ucinet version 6.4, the data is calculated to find out the value of the three indexes, by converted the incidence matrix $(n \times m)$ into the adjacency matrix $(n \times n)$. Then, it is designed that the level of the three indexes is divided into three level - Low, Medium, and High.

\section{Rate of Participation}

Rate of participation ( $\mathrm{RoP}$ ) approach aims to find out the level of participation of respondents in existing community groups [Wasserman \& Faust, 1994]. The data in the affiliation matrix is filled by binary number whereby number 1 means attendance of the respondent in community groups, otherwise equals as zero. The value of the rate of participation varies depends on the presence of the community in participating in the community groups. The more active community in participating in the community groups will be known by the higher value of RoP of that village. There are three classifications of RoP - Low, Medium, and High with a simple calculation that the total number of existing community groups or institutions is divided into three evenly, so it could be used to compare the rate of participation between villages in Bumiaji District. It is assumed that the higher value of RoP of a village, the lower poverty level of its village.

\section{Density}

The density is used to get the average number of activity between respondents [Wasserman \& Faust, 2009]. Density approach is used to know how many numbers of activities that occur by any pair of respondents in each community group. The density value can also be used to see how much the proportion of respondents who share membership in each institution. The value of density is between 0 to 1 and it is classified into three levels of Low $(0-0.333)$, Medium $(0.334-0.666)$, and High $(0.667-1)$. The higher value of density describes a more dense relation among respondents of 
a certain area. The higher value of density describes a more dense relation among respondents of a certain area so that it might result as a non-poverty area.

\section{Centrality}

Similar to the RoP and density, the measurement of centrality uses affiliation data of respondents to the community groups. There are three indices that will be measured covering degree, closeness, and betweenness wherein the formula is developed by Wasserman and Faust (1994). Next, the value of the centralization index is between 0 to 1 with similar classification as it used at the Density.

Basically, the measurement of the centrality index is in order to determine who is the central actor in the community through their memberships in the existing community groups. Degree centrality illustrates the most prominent actors in the network due to the highest number of the actor's affiliation into the existing community group. Betweenness centrality depicts the most important actors in the network because of their 'betweenness' position among two or more other actors. So, they might play important role as the mediator that creates possibility of flow of information as well resources from one side to the other side. Closeness centrality draws the most central actor due to their shortest path to others in the network. Meaning that the actors might reach to others in the network at the shortest 'distance' of time and energy.

\section{RESULTS AND DISCUSSION}

\section{A. Level of Poverty Measurement}

The following Table II illustrates the MPI value at each village, followed by the classification and contribution of deprivation of each dimension whereby this analysis calculates the poverty level of each village.

TABLE II. MPI CALCULATION EACH VILLAGES IN BUMIAJI

\begin{tabular}{|c|c|c|c|c|c|}
\hline \multirow{2}{*}{ Village } & \multirow{2}{*}{$\begin{array}{c}\text { MPI } \\
\text { Value }\end{array}$} & $\begin{array}{c}\text { Classifi } \\
\text {-cation }\end{array}$ & \multicolumn{3}{|c|}{$\begin{array}{c}\text { Contribution of deprivation } \\
\text { in } \\
\text { dimension to overall poverty } \\
(\%)\end{array}$} \\
\cline { 3 - 6 } & & & $\begin{array}{c}\text { Educa- } \\
\text { tion }\end{array}$ & Health & $\begin{array}{c}\text { Living } \\
\text { Standard }\end{array}$ \\
\hline Bulukerto & 0,03 & Very low & 100 & 0 & 0 \\
\hline Bumiaji & 0,03 & Very low & 100 & 0 & 0 \\
\hline Giripurno & 0,03 & Very low & 90 & 0 & 10 \\
\hline Gunungsari & 0,02 & Very low & 100 & 0 & 0 \\
\hline Pandanrejo & 0,03 & Very low & 100 & 0 & 0 \\
\hline Punten & 0,01 & Very low & 50 & 0 & 50 \\
\hline Sumbergondo & 0,08 & Very low & 83 & 0 & 17 \\
\hline Sumberbranta & & Very low & 0 & 0 & 0 \\
\hline s & 0,00 & & & & 0 \\
\hline Tulungrejo & 0,01 & Very low & 100 & 0 & 0 \\
\hline
\end{tabular}

In general, it indicates that the whole nine villages have very low of MPI value. Meaning that none of the villages might be categorized as poor village. Focusing on the dimension of health, it is obviously could be seen that no evidence of malnutrition as well as child mortality in the households of the whole villages based on both primary and secondary data. For the dimension of living standard, majority villages have complete 6 indicators, except the three villages Giripurno, Sumbergondo, and Punten with 10\%, 17\%, 50\% contribution of deprivation, respectively. Different from the other two dimensions, dimension of education of 8 of 9 villages gives significant contribution of deprivation in the very high value in range between $50 \%-100 \%$. In other words, majority of households have at least one family member who did not complete their 12-year schooling.

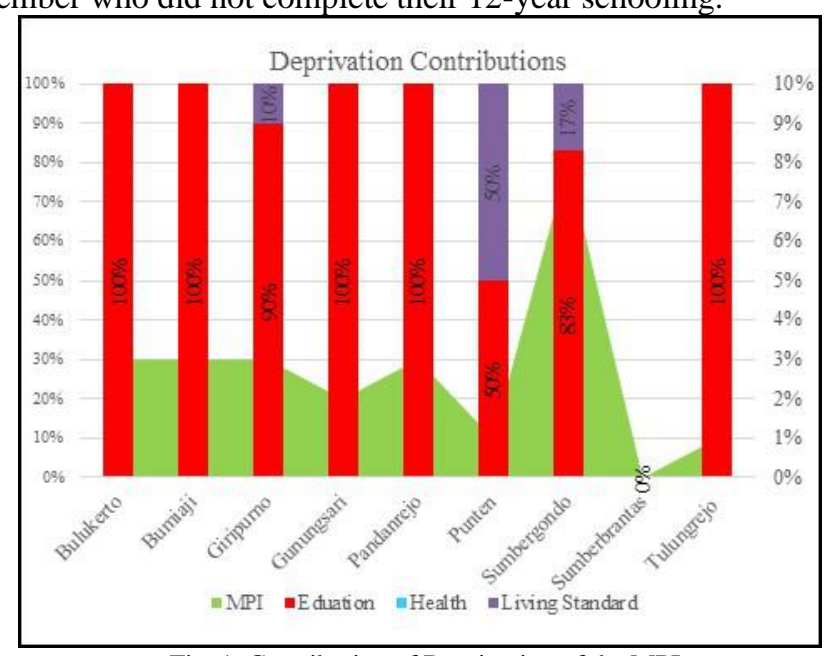

Fig. 1. Contribution of Deprivation of the MPI

Based on Figure 1, in general poverty in Bumiaji District is influenced by the dimension of education and living standard. All MPI values in Bumiaji District is classified in very low value $(<0.09)$. Education dimension has $100 \%$ influence for several villages such as Bulukerto, Bumiaji, Gunungsari, Pandanrejo, and Tulungrejo. Living standard dimension has influence in 3 villages consist of Giripurno, Sumbergondo, and Punten.

\section{B. Social Capital Measurement}

The types of institutions in Bumiaji District might categorize as follows:

1. Religious institutions include Tahlil (Recitation Qur'an for Adult or Married Men or Women), Remas (Youth of Mosque), Pengajian putra (Youth Male Recitation Qur'an) and Pengajian putri (Youth Female Recitation Qur'an). Activity in religious institutions relate to religious activities, such as reading Al-Qur'an together, and study about the meaning, sharing new religious knowledge, etc. Religious institutions in Bumiaji district only have Islamic religion institutions, because the majority people are Muslim. All of the religious institutions have meeting frequency once in a week.

2. Social institutions include Karang Taruna (Youth Club), PKK (Family Welfare Education), Kerja Bakti (Volunteer Activity), and Posyandu (Health Services). Activity in social institutions such as discussions about new information and knowledge, procurement of village activities in celebration of holidays, and so on. Social institutions in Bumiaji District has a two kinds meeting frequency - once in a week, or once in a month.

3. Economic institutions include Arisan (microeconomic group), and GAPOKTAN (Farmer Group). Activity in economic institutions aims to improve the community's economic who incorporated in institutions, savings and loans, empower the farmers, and so on. Economic institutions in Bumiaji District have a similar frequency of meeting with the social institutions. 
TABLE III. NUMBER AND TYPE OF COMMUNITY GROUPS IN BUMIAJI DISTRICT

\begin{tabular}{|c|c|c|}
\hline \multirow{2}{*}{ Village } & \multicolumn{2}{|r|}{ Institution } \\
\hline & Number & Type \\
\hline Bulukerto & 7 & $\begin{array}{l}\text { PKK, Tahlil, Pengajian Putra, Pengajian } \\
\text { Putri, Kerja Bakti, Arisan, Posyandu }\end{array}$ \\
\hline Bumiaji & 7 & $\begin{array}{l}\text { PKK, Tahlil, Pengajian Putra, Pengajian } \\
\text { Putri, Kerja Bakti, Arisan, Karang Taruna }\end{array}$ \\
\hline Giripurno & 10 & $\begin{array}{l}\text { PKK, GAPOKTAN, Tahlil, Pengajian Putra, } \\
\text { Pengajian Putri, Kerja Bakti, Arisan, Karang } \\
\text { Taruna, Remas, Posyandu }\end{array}$ \\
\hline Gunungsari & 8 & $\begin{array}{l}\text { PKK, Tahlil, Pengajian Putra, Pengajian } \\
\text { Putri, Kerja Bakti, Arisan, Karang Taruna } \\
\text { Posyandu }\end{array}$ \\
\hline Pandanrejo & 10 & $\begin{array}{l}\text { PKK, GAPOKTAN, Tahlil, Pengajian Putra, } \\
\text { Pengajian Putri, Kerja Bakti, Arisan, Karang } \\
\text { Taruna, Remas, Posyandu }\end{array}$ \\
\hline Punten & 9 & $\begin{array}{l}\text { PKK, Tahlil, Pengajian Putra, Pengajian } \\
\text { Putri, Kerja Bakti, Arisan, Karang Taruna, } \\
\text { Remas, Posyandu }\end{array}$ \\
\hline Sumber Brantas & 7 & $\begin{array}{l}\text { PKK, Tahlil, Pengajian Putra, Pengajian } \\
\text { Putri, Kerja Bakti, Arisan, Posyandu }\end{array}$ \\
\hline Sumbergondo & 8 & $\begin{array}{l}\text { PKK, GAPOKTAN, Tahlil, Pengajian Putra, } \\
\text { Pengajian Putri, Kerja Bakti, Arisan, } \\
\text { Posyandu }\end{array}$ \\
\hline Tulungrejo & 7 & $\begin{array}{l}\text { PKK, Tahlil, Pengajian Putra, Pengajian } \\
\text { Putri, Kerja Bakti, Arisan, Karang Taruna }\end{array}$ \\
\hline
\end{tabular}

C. Rate of Participation (ROP), Density and Centrality

Table IV demonstrates the level of participation of the respondents into the existing institutions in each village. The highest number of institutions is 10 that is found in the two villages - Giripurno and Pandanrejo. Meanwhile, the lowest number is 7 that can be seen in the four villages - Bulukerto, Bumiaji, Sumbergondo, and Tulungrejo. The rest three villages have 8 and 9 institutions covering Gunungsari, Sumberbrantas, and Punten, respectively.

\begin{tabular}{ccccc} 
TABLE IV. & RATE OF PARTICIPATION IN BUMIAJI DISTRICT \\
\hline Village & $\begin{array}{c}\text { Rate of } \\
\text { Participa } \\
\text { tion }\end{array}$ & $\begin{array}{c}\text { Total } \\
\text { Institution }\end{array}$ & $\begin{array}{c}\text { Classific } \\
\text { ation }\end{array}$ & $\begin{array}{c}\text { Community } \\
\text { Participation in } \\
\text { Institutions }\end{array}$ \\
\hline Bulukerto & 5,03 & 7 & High & $5-6$ institutions \\
\hline Bumiaji & 4.94 & 7 & High & $4-5$ institutions \\
\hline Giripurno & 3.60 & 10 & Medium & $3-4$ institutions \\
\hline Gunungsari & 3.84 & 8 & Medium & $3-4$ institutions \\
\hline Pandanrejo & 4.57 & 10 & Medium & $4-5$ institutions \\
\hline Punten & 4.88 & 9 & Medium & $4-5$ institutions \\
\hline Sumbergondo & 3.23 & 7 & Medium & $3-4$ institutions \\
\hline Sumberbrantas & 5.11 & 8 & Medium & $5-6$ institutions \\
\hline Tulungrejo & 4,89 & 7 & High & $4-5$ institutions \\
\hline When the & RoP & 7 & clasted
\end{tabular}

When the RoP value classified into there level, it can be seen from Table IV that 3 of 9 villages have High level of RoP, meanwhile, the other six villages have Medium level of RoP.

Amongst all, even though Giripurno Village has the Medium of RoP classification (3.60), in average the community has the lowest membership to the existing institutions, wherein they become a member of the 3 to 4 of the total 10 institutions. Based on Statistical Data of Bumiaji District (2018), within the District, the village with the poorest households and the highest number of recipients of the Poverty Alleviation Assistance is located in Giripurno Village. Then, though the level of poverty based on the MPI classification is very low, somehow, living standard and education give significant contribution of deprivation. It seems that the education level influences the social conditions since a low level of education will affect on the low level of community participation. Hereafter, if the level of residents education is low, the willingness of the community to join an institution and share information and other resources is also low.

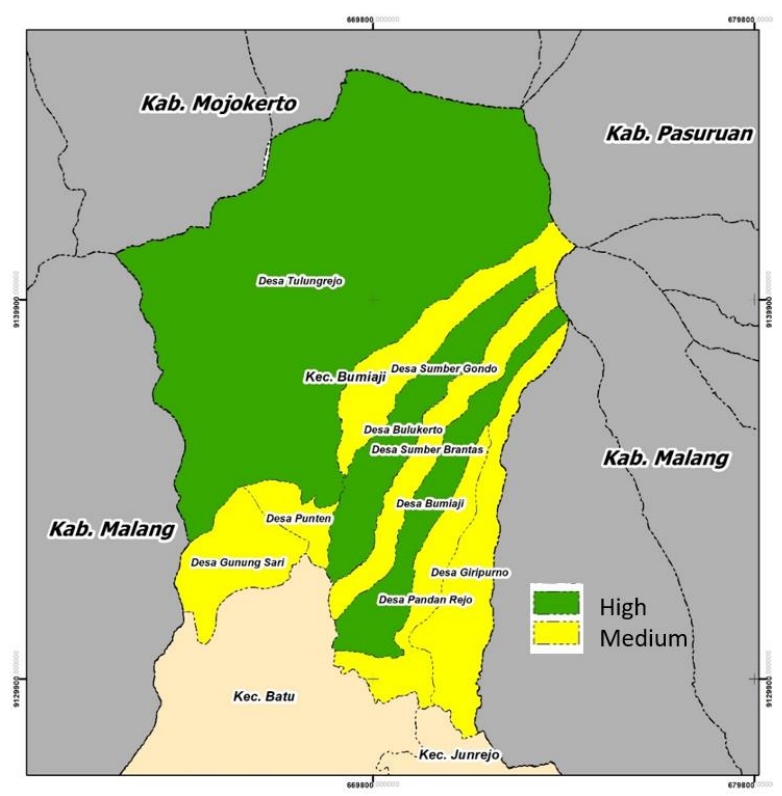

Fig. 1. Map of Rate of Participation Bumiaji District

Figure 1 portrays map of each village with the value of RoP. Though the evidence is quite rare, two clusters are formed by the Medium value of RoP within the two villages, namely Pandanrejo - Giripuro, and Gunungsari - Punten. It is also an interesting fact that the value of RoP between the nearest neighbor in the cluster is quite similar, in the value of 3 and 4 , respectively.

The following Table $\mathrm{V}$ describes the value of Density for each village using UCINET version 6.4 whereby input data is in the form of adjacency matrix with the diagonal value of 0 .

\begin{tabular}{lcc} 
TABLE V. & DENSITY IN BUMIAJI DISTRICT \\
\hline Village & Density & Classification \\
\hline Bulukerto & 1.00 & High \\
\hline Bumiaji & 0.94 & High \\
\hline Giripurno & 0.92 & High \\
\hline Gunungsari & 0.88 & High \\
\hline Pandanrejo & 0.95 & High \\
\hline Punten & 0.84 & High \\
\hline Sumberbrantas & 0.67 & Medium \\
\hline Sumbergondo & 0.99 & High \\
\hline Tulungrejo & 0.95 & High \\
\hline
\end{tabular}

It could be seen that all villages in Bumiaji District have a classification of High density $(0.84-1.00)$, except one village with Medium level namely Sumberbrantas Village. However, the value of the density of Sumberbrantas Village could not be categorized as a low value of social capital since the value is in the highest range of the Medium Level. In other words, there is no gap in social capital between villages.

In general, the high value of density represents on how dense relations among respondents within a village through institutions membership. High social networks provide the possibility for people to interact easier and smoother of 
sharing of information and resources between the member of communities. Then, the high inter-community relations might able to reduce the number of poor households, as it is depicted from the result of MPI.

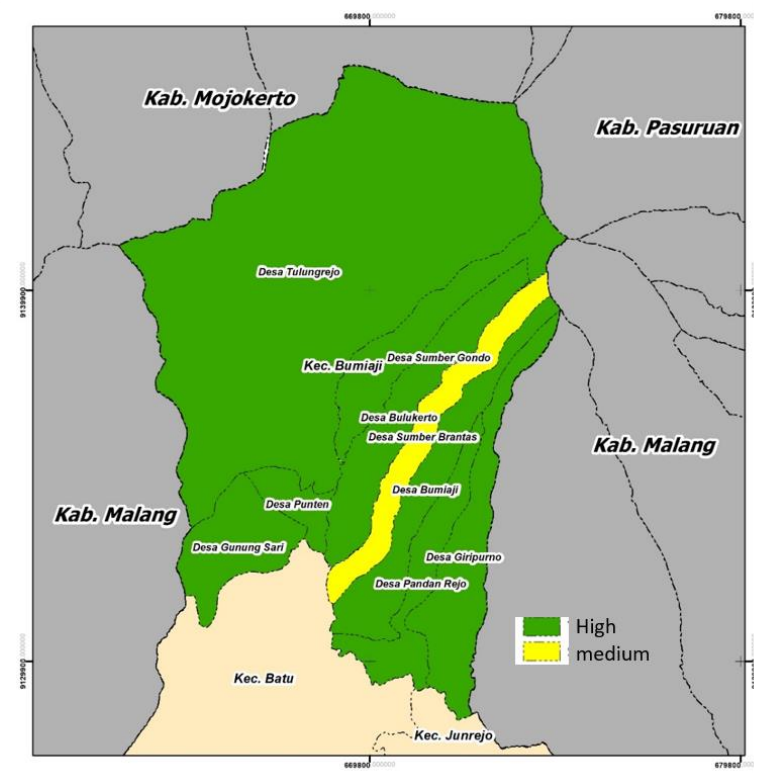

Fig. 2. Map of Density Bumiaji District

The above Figure 2 exemplifies the geographical position between villages with the value of Density. The high value of density might give opportunity among community members within a village to work together for their betterment of life. Moreover, the similarity value in the index of Density and the MPI level between villages might form a resilient community.

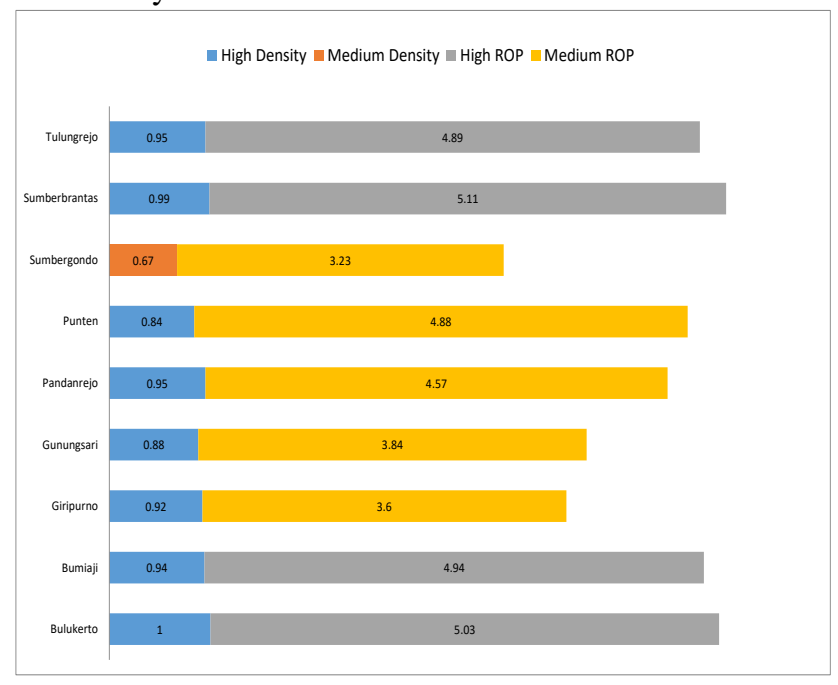

Fig. 3. RoP and Density Bumiaji District

Figure 3 shows that Bumiaji District has 2 classifications of RoP and Density in the High and Medium level. In particular, Sumbergondo Village has the lowest value of participation rate and density.

Table VI illustrates the finding of central actors through three types of Centrality - Degree, Betweenness, and Closeness. The basic difference between the three indexes of the social capital measurement in this research is the two previous indexes (Rate of Participation and Density) exemplify the value of social networks of the village level. Meanwhile, the last index measurement of social capital namely Centrality is to scrutinize who is the most central actors within the network in the scope of the village.

\begin{tabular}{|c|c|c|c|c|c|c|c|c|c|}
\hline \multicolumn{2}{|c|}{ TABLE VI. } & \multicolumn{8}{|c|}{ TABLE DEGREE CENTRALITY BUMIAJI DISTRICT } \\
\hline 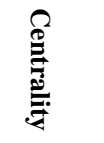 & 餚 & 至 & 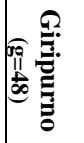 & 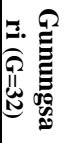 & 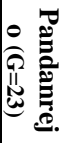 & 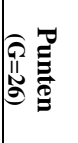 & 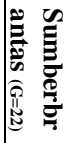 & 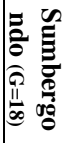 & 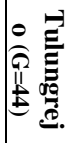 \\
\hline \multicolumn{10}{|c|}{ Degree } \\
\hline Low & 0 & 1 & 1 & 2 & 0 & 2 & 0 & 0 & 1 \\
\hline Medium & 0 & 0 & 2 & 0 & 1 & 0 & 0 & 0 & 0 \\
\hline Hiigh & 29 & 32 & 45 & 30 & 22 & 24 & 22 & 18 & 43 \\
\hline \multicolumn{10}{|c|}{ Betweeness } \\
\hline Low & 29 & 33 & 48 & 32 & 13 & 26 & 22 & 18 & 44 \\
\hline Medium & 0 & 0 & 0 & 0 & 10 & 0 & 0 & 0 & 0 \\
\hline Hiigh & 0 & 0 & 0 & 0 & 0 & 0 & 0 & 0 & 0 \\
\hline \multicolumn{10}{|c|}{ Closeness } \\
\hline Low & 0 & 0 & 0 & 0 & 0 & 0 & 0 & 0 & 0 \\
\hline Medium & 0 & 0 & 0 & 0 & 1 & 0 & 0 & 0 & 0 \\
\hline High & 29 & 32 & 47 & 30 & 22 & 24 & 22 & 18 & 43 \\
\hline
\end{tabular}

In general, the whole villages demonstrate the category composition of a High Degree and Closeness Centrality, and a Low Betweenness Centrality. Majority respondents at every village have a High Degree Centrality meaning that almost every community member is a central actor. In other words, it could be seen that there is no one within the village is the most popular compare to others. In the Closeness Centrality, the respondent who is involved in an institution is calculated, meanwhile, the respondent who is not joined in any kind of institution is expelled from the calculation because none of them might give no contribution to the network (Scott, 2000). In the sense of central actor based on Closeness Centrality, since almost every respondent has high value meaning that almost every respondent has the closest distance to others. In consequence, almost every respondent might able to reach others in the network at the shortest path, so the exchange of information and resources within the network could be done in the fastest way. Then, the third index of Centrality is Betweenness, wherein the whole villages demonstrate the opposite category of the previous two indexes. Meaning that at every village it could not be found a single actor which play role of mediator between other actors, except the 10 respondents in Pandarejo Village who have Medium category of Betweenness Centrality.

TABLE VII. NETDRAW DEGREE CENTRALITY BUMIAJI DISTRICT

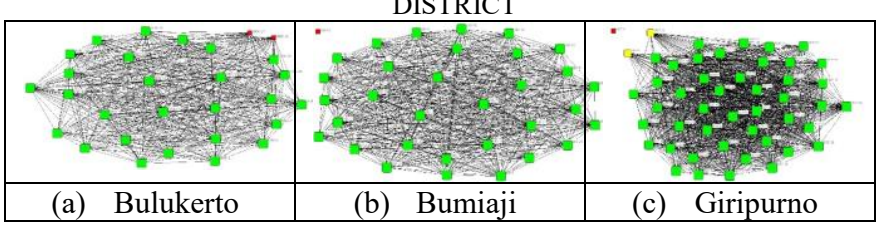




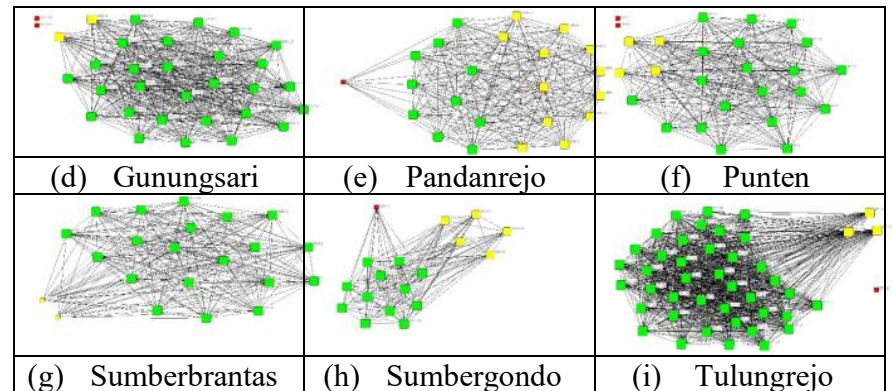

Table VII depicts netdraw of the community members within the network in the scope of each village. It could be seen that there are only a few respondents who did not join into the existing institutions either it is a religious, social, or economy types. There is a very dense linkage that is formed from their institution affiliation wherein almost every community member is related to each other. In the sense of flow of information and resources, the possibility of exchange or mobility will pass from one to another actor directly.

TABLE VIII. NETDRAW BETWEENNESS CENTRALITY BUMIAJI DISTRICT

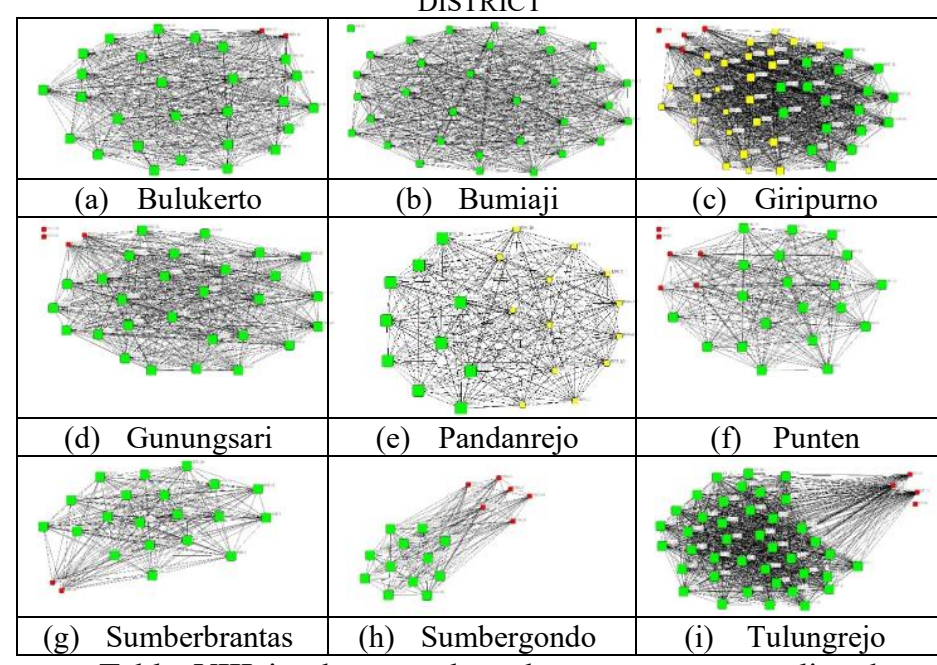

Table VIII is about netdraw betweenness centrality that shows actors who have a role as mediators. At every village in the Bumiaji District has a similar pattern of the network, wherein there is no prominent mediator because almost each of the community member has a direct relationship to each other.

Based on the results of closeness centrality analysis in 9 villages in Bumiaji District, it shows that the respondent possesses a level of centrality for participation in institutions in Bumiaji District in the high category. The high value of closeness centrality in villages in the District of Bumiaji might provide benefits in the delivery of information and resources due to the rapid interaction between respondents. The function of the rapid delivery of information could affect the rapid response of the community in activities that would be held as an effort to improve the welfare of the people of Bumiaji District.

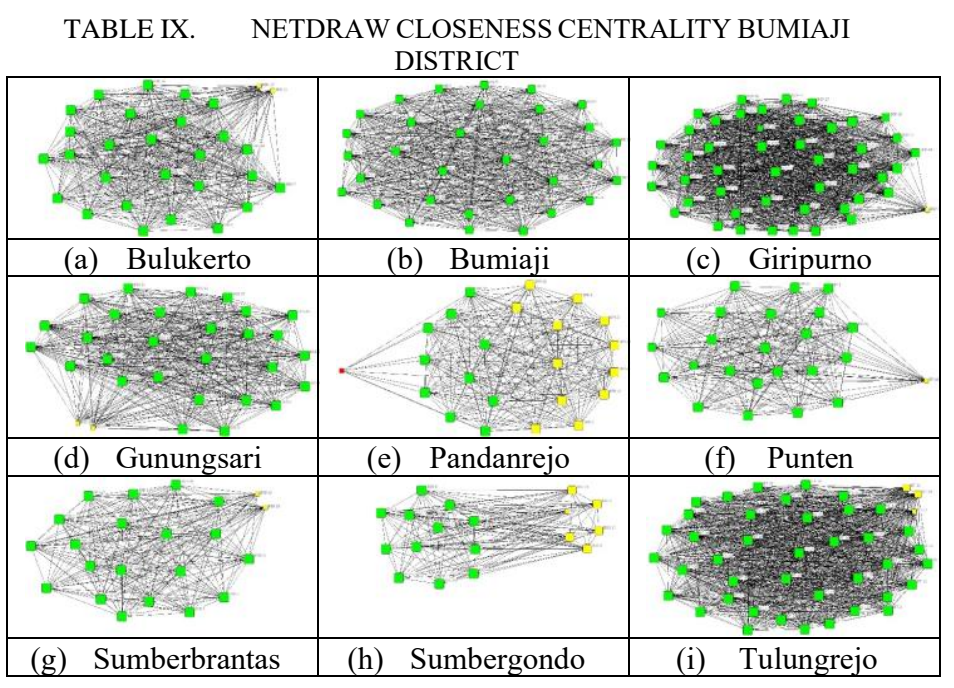

The color on netdraw shows the value of centrality, the green color indicates a high value, the yellow color indicates a medium value and the red color indicates a low value. The results of net draw analysis on degree centrality, betweenness centrality, and closeness centrality can be seen that there are a lot of green colors on the net draw that indicates that there are many central actors or it could be stated that there is no central actor who plays most influential role because all actors play an active role in the institution.

TABLE X. SOCIAL CAPITAL CLASSIFICATION IN BUMIAJI

\begin{tabular}{|c|c|c|c|c|c|}
\hline \multirow{2}{*}{ Village } & \multirow{2}{*}{$\begin{array}{c}\text { Rate of } \\
\text { Participation }\end{array}$} & Density & \multicolumn{3}{|c|}{ Centrality } \\
\cline { 4 - 6 } & High & High & $\begin{array}{c}\text { Cdigh } \\
(29)\end{array}$ & $\begin{array}{c}\text { Low } \\
(29)\end{array}$ & $\begin{array}{c}\text { High } \\
(29)\end{array}$ \\
\hline Bulukerto & High & High & $\begin{array}{c}\text { High } \\
(32)\end{array}$ & $\begin{array}{c}\text { Low } \\
(32)\end{array}$ & $\begin{array}{c}\text { High } \\
(32)\end{array}$ \\
\hline Bumiaji & Medium & High & $\begin{array}{c}\text { High } \\
(45) \\
\text { Medium } \\
(2)\end{array}$ & $\begin{array}{c}\text { Low } \\
(48)\end{array}$ & $\begin{array}{c}\text { High } \\
(47)\end{array}$ \\
\hline Gunungsari & Medium & High & $\begin{array}{c}\text { High } \\
(30)\end{array}$ & $\begin{array}{c}\text { Low } \\
(32)\end{array}$ & $\begin{array}{c}\text { High } \\
(30)\end{array}$ \\
\hline Pandanrejo & Medium & High & $\begin{array}{c}\text { High } \\
(22) \\
\text { Medium } \\
(1)\end{array}$ & $\begin{array}{c}\text { Medium } \\
(10) \\
\text { Low } \\
(13)\end{array}$ & $\begin{array}{c}\text { High } \\
(22) \\
\text { Medium } \\
(1)\end{array}$ \\
\hline Punten & Medium & High & $\begin{array}{c}\text { High } \\
(24)\end{array}$ & $\begin{array}{c}\text { Low } \\
(26)\end{array}$ & $\begin{array}{c}\text { High } \\
(24)\end{array}$ \\
\hline Sumbergondo & Medium & Medium & $\begin{array}{c}\text { High } \\
(22)\end{array}$ & $\begin{array}{c}\text { Low } \\
(22)\end{array}$ & $\begin{array}{c}\text { High } \\
(22)\end{array}$ \\
\hline Sumberbrantas & Medium & High & $\begin{array}{c}\text { High } \\
(18)\end{array}$ & $\begin{array}{c}\text { Low } \\
(18)\end{array}$ & $\begin{array}{c}\text { High } \\
(18)\end{array}$ \\
\hline Tulungrejo & High & High & $\begin{array}{c}\text { High } \\
(43)\end{array}$ & $\begin{array}{c}\text { Low } \\
(44)\end{array}$ & $\begin{array}{c}\text { High } \\
(43)\end{array}$ \\
\hline
\end{tabular}
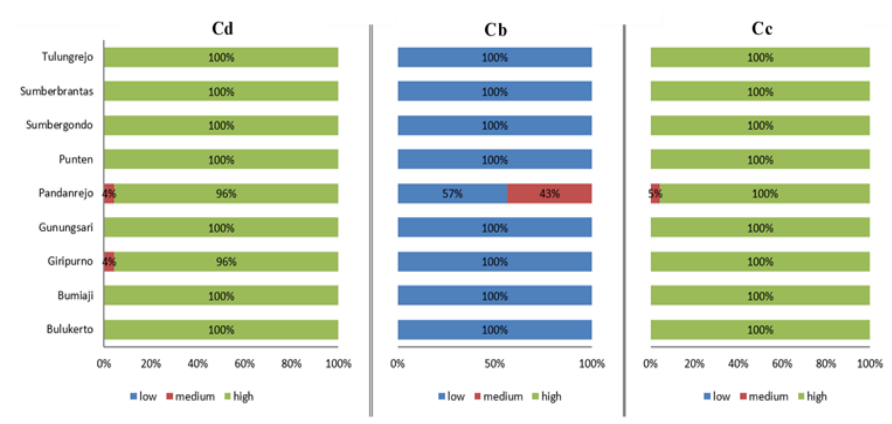

Fig. 4. The centrality of Bumiaji District 
The classification of centrality within the brackets in Table $\mathrm{X}$ shows the number of actors in each village. As a whole, the strongest pattern of social capital in Bumiaji District through Degree - Betwenness - Closeness Centrality is a High - Low - High, respectively. The structure of social capital that is formed by the fifth indexes could be classified into 6 types in order of RoP - Density - Degree - Betweenness - Closeness Centrality:

1. High - High - High - Low - High $\rightarrow 3$ villages;

2. Medium-High - High/Medium - Low - High $\rightarrow 1$ village;

3. Medium-High - High/Medium - Medium/Low High/Medium $\rightarrow 1$ village;

4. Medium-High - High/Medium - Medium/Low High/Medium $\rightarrow 1$ village;

5. Medium-High - High - Low - High $\rightarrow 2$ villages;

6. Medium - Medium - High - Low - High $\rightarrow 1$ village.

The MPI analysis indicates that 9 villages in Bumiaji District could not be classified as poor villages in a multidimensional manner. The results of two analyses that have been carried out indicate that villages in Bumiaji District that are not poor have good social capital. Based on the theory [Putnam, 2000] which states that the condition of a good social capital community will make it easier to alleviate poverty because with a good condition of social capital it has an impact on the mobilization of good information and human resources. Good relations between communities might make it easier for people to access information and resources more easily, so as to improve the quality of the community.

\section{CONCLUSION}

Poverty in the District of Bumiaji is reviewed through three variables, namely Education, Health, and Living Standard. The results of the analysis stated that the poverty level in Bumiaji District is classified as very low. However, there are two dimensions that give a significant contribution of deprivation, so one of the strategies of poverty reduction in the district is the necessary development of the dimension of education and living standard.

Social dimensions include trust and norms, networking, and institutional decision making. Based on the analysis results in the research, it is found that the high rate of participation and density showed that the social network of the community was getting closer or closer. High community social networks provide the possibility for people to more easily interact and share information and resources between the member of communities. The level of community participation and density values in Bumiaji sub-district shows that the community has not been able to independently alleviate poverty that occurs, and still needs government assistance because it is known that the number of recipients of poverty assistance from the government is still high. Education level influences social conditions because a low level of education will affect the level of community participation which is also low. If the level of public education is low, then the willingness of the community to join an institution and share information and resources are also low.

The high social relations of the community also indicate that there is no central actor who stands out in the activity because between the member of communities there is a close direct relationship. Community activity can provide convenience in efforts to improve the welfare of the people of Bumiaji District because active people are more open to new things and have a positive impact on the community. High levels of community activity can be considered for village development activities or other program activities to improve village welfare and alleviate social problems such as inequality or poverty.

Social relations might reduce poverty because in connectivity between social networks there is an exchange mechanism of resources such as the flow of information, employment opportunities, financial support, or learning between poor and non-poor communities (Grootaert, 2001). Good social capital is characterized by strong social institutions; social capital creates a harmonious social life (Putnam, 1995). The condition of poverty in Bumiaji is classified as very low with a good social capital, which states the relationship between poverty and social capital. Hence, it might conclude the proof of the condition of social capital might open higher opportunity for the community in the problem of poverty because with a good condition of social capital it will be easier to deliver information as well resources so that it can improve the quality of the community.

The focus of the research is in the scope of village, whereby it could be seen that the social network within the village is very dense. So the netdraw might illustrate a tendency of inward-looking of the social capital within the village. Meanwhile, it seems that the character of the nearest neighborhoods might have similar character. In the sense of a village that is surrounded by or neighbors with poor villages indicated by low social capital, it becomes more difficult for the village to move out of poverty. Then, for the future research it is planned to measure social capital of the whole district by adding some key persons who join institutions in the higher level such as at the district level due their wider network. Hence, a better understanding of how to utilize social capital on dealing with poverty reduction would be reached.

\section{ACKNOWLEDGMENT}

This research is funded by the Indonesia Ministry of Research, Technology and Higher Education. Sincere gratitude for my solid team - Anestia Lairatri Prabandari, Nidyaul Elya, Bayu Seno Aji, Nadine Putri W.

\section{REFERENCES}

[1] Alfiah, R., Ari, I. R. D., Maulidi, C. 2017. Community Participation in Fulfillment of Rural Clean Water Needs. Planning for Urban Region and Environment Journal. Vol. 3 No. 3. Malang: Brawijaya University

[2] Ari, I. R. D. 2011. Dissertation: Participatory Approach to Community Based Water Supply System. Kyoto: Kyoto University Research Information Repository.

[3] Ari, I. R. D., K. Ogi, K. Matsushima, dan K. Kobayashi. 2013. The Sixth Workshop on Social Capital and Development: Community Networks, Social Capital, and Access To Drinking Water IOP.

[4] Ari, I. R. D., A. W. Hasyim, B. A. Pratama, M. Helmy, dan M. N Sheilla. 2017. IOP Conf. Series: Earth and Environmental Science 70 (2017) 012017 - Infrastructure and social tie: Spatial model approach on understanding poverty in Malang regency, Indonesia. Paper Open Access at IOP Conference Series: Earth and Environmental Science.

[5] Ari, I. R. D., Wijaya, I. N. S., Dewanto, A. 2018. Community Participation on Urban Sanitation Program: Comparison Study. IOP Conference Series Earth and Environmental Science 158(1):012013 
[6] Grootaert, C. (2001). Does Social Capital Help the Poor?: A Synthesis of Findings from the Local Level Institutions Studies in Bolivia, Burkina Faso and Indonesia. Local Level Institutions Working Paper, 10. Social Development Department - The World Bank. Diakses dari http://documents.worldbank.org/curated/en/368221468743373459/p df/multiopage.pdf.

[7] Putnam R., and J.F. Helliwell, 1995, "Social Capital and Economic Growth in Italy”, Eastern Economic Journal, Vol. 21, pp. 295-307.

[8] Putnam, R.D. 2000. Bowling Alone: The Collapse and a Revival of American Community. New York: Simon and Schuster

[9] Research Team MPI Indonesia, 2015 Modul Pelatihan Perhitungan Multidimensional Poverty Index Indonesia dan Penyusunan Pelaporan MPI Indonesia Perkumpulan Prakarsa

[10] Santoso, et al. 2009. Ilmu Keperawatan Komunitas Konsep dan Aplikasi Buku 2. Jakarta: Salemba Medika.
[11] Scott, John. 2009. Social Network Analysis. London.Sage

[12] Vippriyanti, N. U. 2011. Modal Sosial dalam Pembangunan WI;ayah. Malang: UB Press.

[13] Wasserman, Stanley, and Katherine Faust. 1994. Social Network Analysis: Methods and Applications. American Ethnologist. Vol. 24. doi:10.1525/ae.1997.24.1.219

[14] Wasserman, Stanley \& Fraust, K. 2009. Social Network Analysis: Methods and applications. New York:Cambridge University

[15] World Bank. 2001. Understanding and Measuring Social Capital: A Synthesis of Findings and Recommendations From the Social Capital Initiative. Social Capital Initiative Working Paper No. 24. Washington: Social Development Department Publications.

[16] Yamin, Sofyan and Teguh Dartanto, 2017 Pengentasan Orang Miskin di Indonesia: Peran Modal Sosial yang Terlupakan Poverty Alleviation in Indonesia: The Missing Link of Social Capital Jurnal Ekonomi dan Pembangunan Indonesia Vol. 17 No. 1. 